\title{
When free flaps are not the first choice: is the distally based peroneus brevis still an option for foot and ankle reconstruction in the era of microsurgery?
}

\author{
Raymund E. Horch ${ }^{1}$, Ingo Ludolph ${ }^{1}$, Marweh Schmitz ${ }^{1}$, Anja M. Boos ${ }^{1}$, Ulrich Kneser ${ }^{1,2}$, Justus P. Beier ${ }^{1,3}$, \\ Andreas Arkudas ${ }^{1}$
'Department of Plastic and Hand Surgery, University Hospital Erlangen, Friedrich-Alexander University Erlangen-Nuernberg FAU, Erlangen D-91054, Germany.
2Department of Hand, Plastic and Reconstructive Surgery-Burn Center-BG Trauma Center Ludwigshafen, Department of Plastic Surgery, University of Heidelberg, Ludwigshafen D-67071, Germany. \\ ${ }^{3}$ Department of Plastic Hand and Burn Surgery, University Hospital RWTH, Aachen D-52074, Germany.
}

Correspondence to: Prof. Raymund E. Horch, Department of Plastic and Hand Surgery, University Hospital Erlangen, FriedrichAlexander University Erlangen-Nuernberg FAU, Erlangen D-91054, Germany. E-mail: raymund.horch@uk-erlangen.de

How to cite this article: Horch RE, Ludolph I, Schmitz M, Boos AM, Kneser U, Beier JP, Arkudas A. When free flaps are not the first choice: is the distally based peroneus brevis still an option for foot and ankle reconstruction in the era of microsurgery? Plast Aesthet Res 2018;5:26. http://dx.doi.org/10.20517/2347-9264.2018.25

Received: 16 Apr 2018 First Decision: 23 Jul 2018 Revised: 24 Jul 2018 Accepted: 24 Jul 2018 Published: 31 Jul 2018

Science Editor: Raymund Engelbert Horch Copy Editor: Jun-Yao Li Production Editor: Huan-Liang Wu

\begin{abstract}
Aim: Soft tissue defects with or without exposed bones in the lower extremity, ankle and the foot-with or without bone defects or exposed hardware-often require coverage with vascularized flaps. Free flaps, which add healthy tissue especially to the lower extremity instead of further injuring a limb, are the first choice in high volume microsurgical centres. Nevertheless, in some instances pedicled flaps may have indications when free flaps are not suitable.
\end{abstract}

Methods: The distally based peroneus brevis flap is harvested from the lateral compartment of the leg based on the distal perforating arterial supply and covered with split skin.

Results: We performed a total of 69 peroneus flaps between 2003 and 2017. Minor flap necroses at the distal tip were noted in $8 \%$ of the peroneus brevis reconstructions. Total flap loss occurred in 1 peroneus flap. Defect etiology and patient age were not associated with surgical outcome.

Conclusion: While nowadays the first choice of lower extremity reconstruction is an appropriate free flap solution,

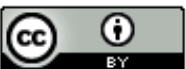

(C) The Author(s) 2018. Open Access This article is licensed under a Creative Commons Attribution 4.0 International License (https://creativecommons.org/licenses/by/4.0/), which permits unrestricted use, sharing, adaptation, distribution and reproduction in any medium or format, for any purpose, even commercially, as long as you give appropriate credit to the original author(s) and the source, provide a link to the Creative Commons license, and indicate if changes were made.

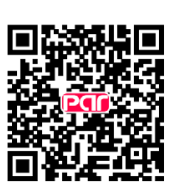


the peroneus brevis muscle flap can also be seen as a valuable tool to reconstruct small to medium sized defects at the ankle, distal tibia, and the heel with an acceptable donor site morbidity. Despite the easily available variety of free flaps to achieve this purpose, still proper indications remain where a local flap can be a viable option in the hand of experienced plastic surgeons. However, caution is advisable in patients with peripheral arterial occlusive disease or venous insufficiency.

Keywords: Free flaps, peroneus brevis, muscle flap, lower extremity reconstruction

\section{INTRODUCTION}

Soft tissue defects-with or without bone defects or exposed hardware-in the lower extremity, ankle and the foot often require coverage with vascularized flaps. Due to the anatomically given thin layer of soft tissue to cover vital structures and the oftentimes limited blood supply, the amount of locally available skin is very limited.

Free flaps have become a routine procedure and are a superb option in many cases, especially when large and complex defects need to be addressed. A variety of available options have been described for this problem $z e^{[1-15]}$. However, when either the local conditions or other obstacles including systemic diseases, that limit an extended operation time or missing microsurgical expertise are hindrances to closure, local flaps may be a solid option. Proximally based pedicled local flaps have a limited arc of rotation and therefore are no good candidates to reconstruct defects in the lower third of the leg, ankle or foot. We describe the use of a distally based peroneus brevis flap for indications where free flaps were not suitable or not deemed the first priority.

In such cases distally based muscle and fasciocutaneous flaps have constantly remained an interesting alternative to free flap surgery. While the distally based peroneus brevis muscle flap (PBF) was first reported by Donski and Fodgestan ${ }^{[16]}$, it became more popular when Masquelet described the surgical procedure in detail based on of his anatomical findings ${ }^{[17]}$ and by Lyle and Colborn ${ }^{[18]}$. In our clinical routine it has been implemented as a workhorse for reconstructing small full thickness defects in the distal lower leg, ankle and heel ${ }^{[19-24]}$. Later papers added their experiences and highlighted the key points that need to be taken into account McHenry et al. ${ }^{[25]}$ and Eren et al. ${ }^{[26]}$.

Because the anatomy is relatively constant this flap can be quickly and reliably harvested and the donor site poses no relevant clinical or functional problem. This flap has therefore been successfully applied by various authors to reconstruct the distal lower leg, ankle and Achilles region ${ }^{[4,27-29]}$. We discuss the peroneus brevis flap as a part of the surgical armamentarium and hence its specific technical aspects in this paper.

\section{METHODS}

According to the description of Nahai and Mathes ${ }^{[30]}$ who had first reported the peroneus brevis flap as a proximally based tool in 1974 later on described a distally based version in 1997, we performed the distally based turnover muscle flap. Modifications and standardization of this flap ${ }^{[18]}$ were popularized by Eren et al. ${ }^{[26]}$ and further propagated by others as a useful muscle flap to reconstruct small defects in the lateral distal third of the leg ${ }^{[4,31-34]}$.

In our series the peroneus brevis flap was raised as a reversed muscle flap and, following transfer into the defect, covered with a split thickness skin graft. Donor sites were closed directly in all flaps ${ }^{[35]}$. Similar to patients with sural flaps, wounds were preconditioned using topical negative pressure with or without instillation until the wound was deemed clean enough for closure. Dissection of the flap was performed under general anaesthesia with the patient supine on the operative table and a tourniquet was applied. The incision was performed straight or slightly curved depending on the localization of the defect. Preserving 


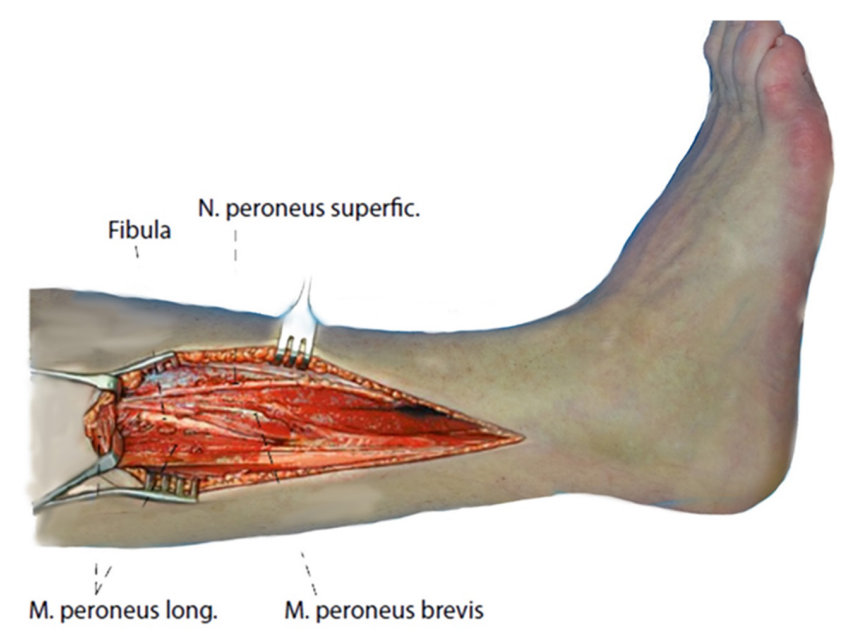

Figure 1. Anatomy of the lateral lower leg with marked peroneus brevis muscle

the distal perforating vessel, which is approximately $5 \mathrm{~cm}$ above the malleolus has allowed the flap to become adopted as a standard technique of limb reconstruction in our unit with 1 case of total PBF flap loss so far, requiring secondary surgery.

Skin flaps were raised with the deep fascia, and care was taken to protect the superficial branch of the peroneal nerve, which can be dissected deep to the deep fascia in the proximal calf. It pierces the deep fascia approximately $15 \mathrm{~cm}$ proximal to the lateral malleolus. The peroneus longus tendon is found more posterior and superficial than its brevis counterpart. The tendons were followed up to the attachments of the muscle bellies and brevis and longus tendon were identified and separated, revealing the lateral surface of the fibula between them. Any branches of the peroneal vessels that run posterior to the fibula and segmentally pierce the muscle should be protected. In our series we found usually one larger proximal vessel and another smaller one more distally. The peroneus muscle was then detached from the anterior intermuscular septum to the anterior surface of the fibula. The muscle was elevated en bloc starting from the periosteum proximally down to the pivot point, where the dissection stopped. Two thirds of the flap can usually be elevated until the perforating vascular branch enters the muscle belly. After opening the tourniquet and hemostasis the flap was turned over and was sutured into place with a drainage underneath and split skin grafts on top. If necessary near infrared fluorescent angiography with indocyanine green was performed intraoperatively to determine flap perfusion and to eventually trim the tip of the flap. Eventually the most distal tip of the peroneus flap is prone to undergo venous congestion and may necessitate secondary skin regrafting, which usually leads to complete healing [Figures 1-5].

In a previous historic comparison of reverse flow lower extremity flaps Kneser et al. ${ }^{[36]}$ analyzed the morbidity of the donor site and stated that equally to a reversed sural island flap (which was used historically and is no longer a routine surgical option in our hands since free flaps have become the method of choice) the peroneus brevis flap showed appropriate to successfully close full thickness defects in the lower extremity.

\section{RESULTS}

We performed a total of 69 peroneus flaps between 2003 and 2017. Minor flap necroses at the distal tip were noted in $8 \%$ of the peroneus brevis reconstructions. Total flap loss occurred in 1 peroneus flap. Defect etiology and patient age was not associated with surgical outcome.

In a physical examination at time points with a minimum of at least 12 months after flap surgery all wounds 


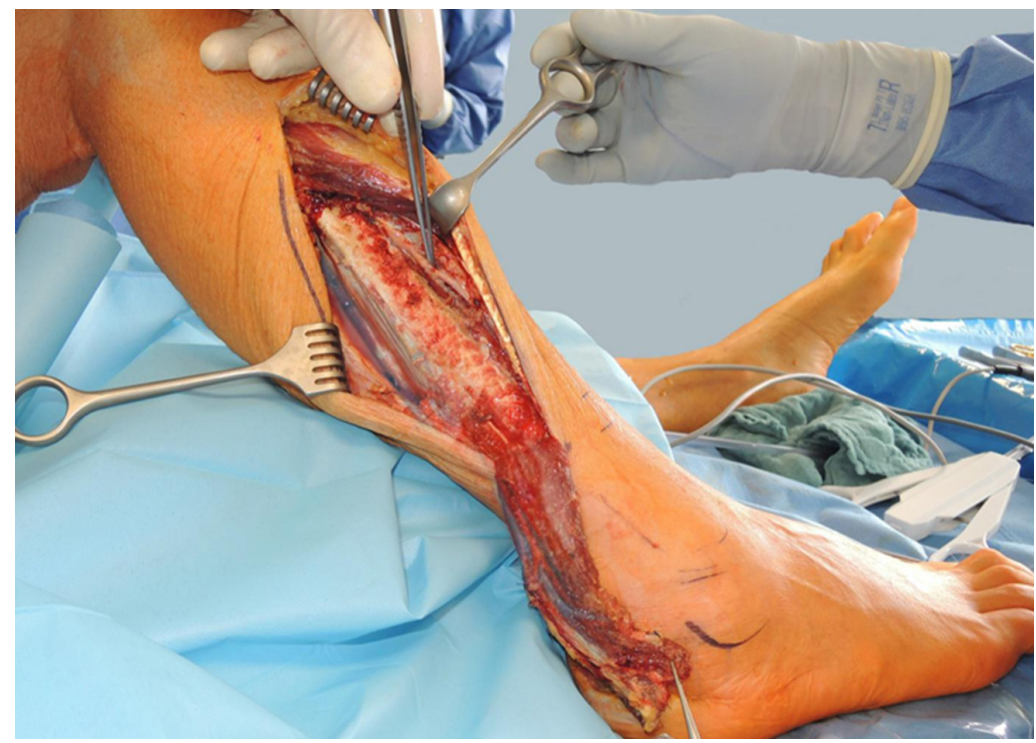

Figure 2. The 75-year-old patient with intraoperative raised distally based peroneus brevis muscle with flap turned and flipped over to 180 degrees into defect zone of a chronic wound after open reduction and internal fixation of calcaneal fracture

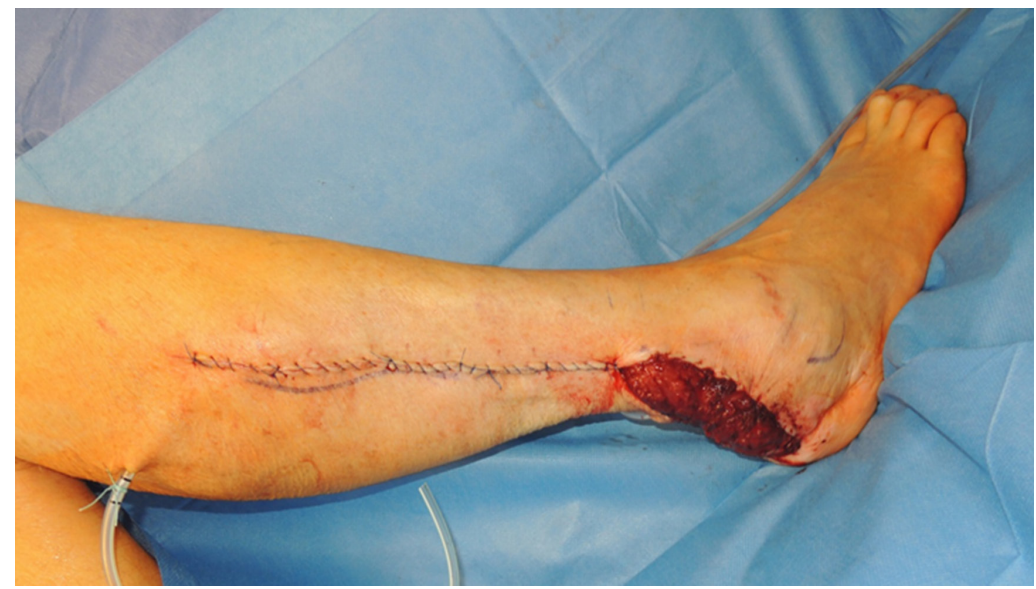

Figure 3. Primary closure of donor site with distally based peroneus brevis muscle flap sutured into place before skin grafting

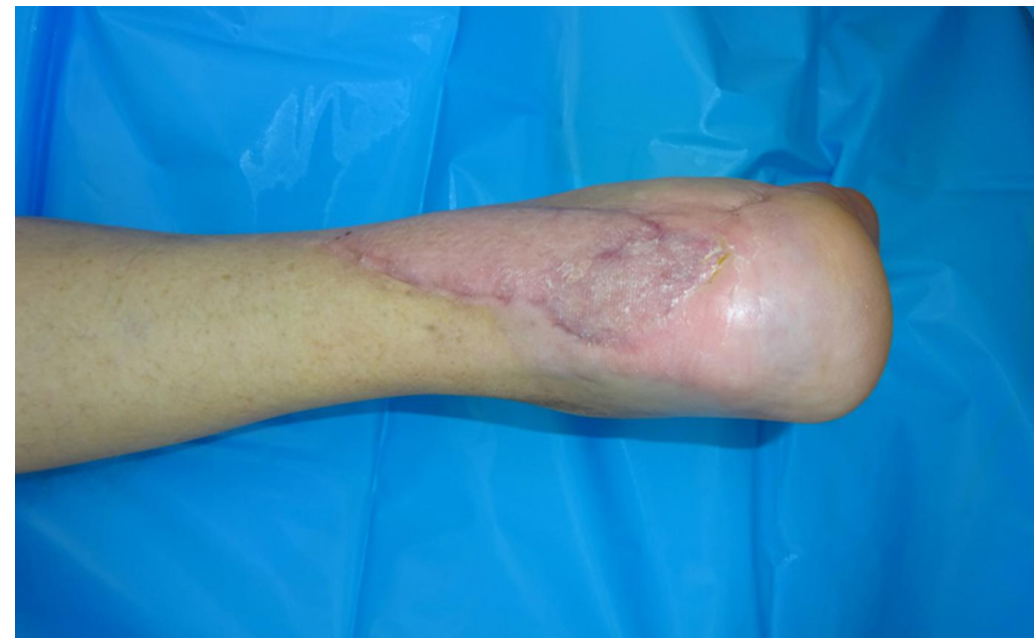

Figure 4. Dorsal aspect of the reconstructed heel region 6 months after surgical therapy 


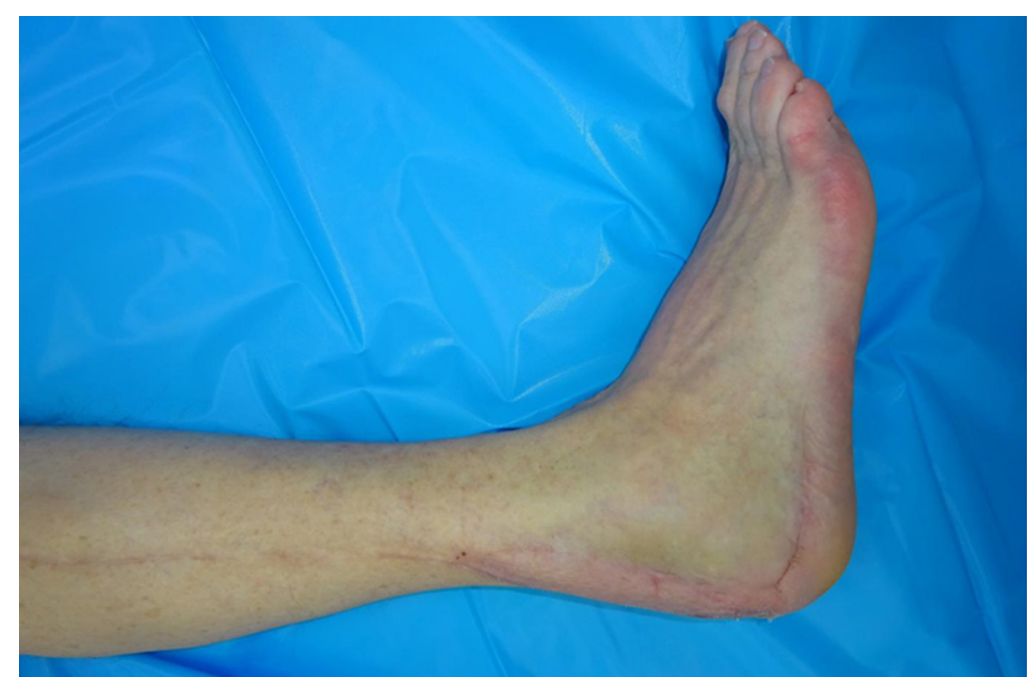

Figure 5. Lateral aspect of the lower leg and foot 6 months after reconstruction with the distally based peroneus brevis muscle flap and split-thickness skin graft. The distal part of the flap needed secondary skin regrafting and hence healed uneventfully

were completely healed without any evidence of instable scars, chronic infections or fistulae. Patients reported a high level of satisfaction regarding the outcome of surgery without any significant statistical difference between the compared flaps. The active total range of motion was comparable in both groups without significant differences [extension/flexion 78.5\% $\pm 20.0 \%$ (PBF peroneus flap), $66.6 \% \pm 23.1 \%$ (DSF distal sural flap) and pronation/supination $70.9 \% \pm 27.7 \%$ (PBF), $61.1 \% \pm 33.3 \%$ (DSF)]. No instability of the ankle joint was observed in patients from both groups. Circumference of the lower leg $15 \mathrm{~cm}$ below the knee joint and above the ankle joint was comparable in both groups. No significant postoperative lymphedema was observed. Hypaesthesia in the lower leg or foot region, except for the flap itself and the skin-grafted regions at the donor site, was reported by $21 \%$ of patients from the PBF and $58 \%$ of patients from the DSF group $^{[36]}$. Patients did not report significant functional impairment due to these hypoaesthetic zones. Neuromas were neither observed at the donor nor at the recipient sites in this series ${ }^{[36]}$.

\section{DISCUSSION}

Soft tissue defects in the distal lower leg as well as in the foot and ankle region are not infrequent and remain challenging for plastic surgery. Methods of tissue engineering and regenerative medicine ${ }^{[37-51]}$ to circumvent the use of autologous tissue and their inherent donor site morbidity seem promising but are not clinically available for these problems yet. Although a considerable number of local or free flaps has been successfully described to surgically reconstruct these defects ${ }^{[7,52-58]}$ each individual case needs the optimal indication for the most suitable flap procedure. Free flap transfer has become a routine method in high volume centers and allow free tissue transfer even to the distal lower extremity with a successful closure in more than $90 \%-95 \%$, depending on the comorbidities and local and systemic conditions. This does not preclude the remaining interest in local flaps to solve the problem of small to medium-sized defects in this critical anatomical $\operatorname{region}^{[59,60]}$.

Especially the advent of perforator based flaps, such as propeller flaps, have augmented the armamentarium of problem solving techniques in the lower extremity ${ }^{[52]}$. Other than in the proximal knee region and the upper and middle third of the lower leg, where a variety of proximally based local pedicled flaps are available, the lower third and foot and ankle region demand either free flaps or reversed pedicled flaps ${ }^{[1,61,62]}$. Various modifications of the sural and peroneusbrevis flaps have been described to optimize the outcome and minimize complications ${ }^{[63-67]}$. The distally based peroneus brevis flap has been described as an efficient tool for the reconstruction of the distal lower leg, ankle, Achilles tendon and proximal foot region ${ }^{[4,65,68-73]}$. This flap can be indicated to cover exposed vessels, bones, tendons, and internal fixation hardware. 
The surgical procedure is comparatively straight forward and basically safe, when anatomical landmarks and precautions are taken into account. Although we no longer use the distally based sural fasciocutaneous flap our group has compared the efficacy and donor site morbidity following use PBF (when compared to a sural flap) which had not been studied earlier ${ }^{[32]}$. Using the foot and ankle outcome score (FAOS) a direct comparison between the sural flap and the peroneus flap group did not show significant differences in any of the FOAS subscales ${ }^{[36]}$. Interestingly, the general quality of life (QOL) in patients with distally based flaps was more reduced in both groups than the actual function in daily living (ADL). In an attempt to exclude the influence of initial defect-related problems on ankle stability and function, subgroups of patients with defects caused by open fractures, osteomyelitis or Achilles tendon-related defects were compared with defects secondary to tumor resection or ulcers ${ }^{[36]}$. The results from the patient-administered FOAS questionnaire were confirmed by the physical examination which did not identify any significant differences in terms of ankle joint stability or range of motion $^{[36]}$.

Ulrasonic investigation may further enhance the safety of the procedure. As with other meta-analyses it is a commonly known problem in studying outcomes in reconstructive surgery, that most series comprise only small numbers of patients and lack randomized trials, which is a classical scenario in plastic surgery. This holds especially true for studies comparing different types of flaps, where personal experience and preferences as well as local conditions significantly influence decision-making and prevent randomization ${ }^{[9,36]}$. The use of near infrared laser angiography with indocyanine green intraoperatively might help further optimize the design and flap survival, as has been shown previously in other flaps ${ }^{[14,74]}$.

In conclusion, distally based peroneus brevis flaps remain valuable options for the reconstruction of full thickness defects in the distal lower leg when the routine use of free flaps is not indicated. Vascular integrity of the affected leg is a prerequisite, and if local perfusion is compromised by peripheral vascular disease, failure rates are higher. In such cases we strongly advocate the use of free flaps with vascular reconstructions and optimization of blood flow. Studies have shown that harvesting of PBF does not affect stability and ROM of the ankle joint.

Whenever free flaps are not the first choice in distal lower leg reconstructions we therefore would recommend the peroneus brevis muscle flap as an alternative procedure to close small to medium sized defects at the distal tibia, fibula, ankle and heel.

\section{DECLARATIONS}

\section{Acknowledgments}

Some of the results have been part of Silke Brockmann's doctoral thesis and have been published previously ${ }^{[36]}$.

\section{Authors' contributions}

Performed operations, wrote the manuscript draft, literature research, and corrected versions: Horch RE Performed operations, helped analyze results and worked on the manuscript: Ludolph I, Schmitz M, Boos AM, Kneser U, Beier JP, Arkudas A

\section{Availability of data and materials}

Results are reported in the manuscript, patient's individual data are not available to the public for the sake of data protection laws.

\section{Financial support and sponsorship}

None.

\section{Conflicts of interest}

All authors declare that there are no conflicts of interest. 


\section{Ethical approval and consent to participate}

Ethical approval is not applicable. Each patient has signed an informed consent that his data may be anonymously utilized for scientific reasons.

\section{Consent for publication}

Not applicable.

\section{Copyright}

(c) The Author(s) 2018.

\section{REFERENCES}

1. Ademoğlu Y, Ozerkan F, Ada S, Bora A, Kaplan I, Kayalar M, Kul F. Reconstruction of skin and tendon defects from wound complications after Achilles tendon rupture. J Foot Ankle Surg 2001;40:158-65.

2. Akyurek M, Fudem G, Leclair W, Babbitt R, Dunn RM. Salvage of a lower extremity by microsurgical transfer of tibial bone from the contralateral extremity traumatically amputated at the ankle level. Ann Plast Surg 2009;63:389-92.

3. Arnold PG, Irons GB. Lower-extremity muscle flaps. Orthop Clin North Am 1984;15:441-9.

4. Bach AD, Leffler M, Kneser U, Kopp J, Horch RE. The versatility of the distally based peroneus brevis muscle flap in reconstructive surgery of the foot and lower leg. Ann Plast Surg 2007;58:397-404.

5. Bajantri B, Bharathi RR, Sabapathy SR. Wound coverage considerations for defects of the lower third of the leg. Indian J Plast Surg 2012;45:283-90.

6. Chen SL, Chuang CJ, Chou TD, Chen TM, Wang HJ. Free medial sural artery perforator flap for ankle and foot reconstruction. Ann Plast Surg 2005;54:39-43.

7. Daigeler A, Kneser U, Fansa H, Riester T, Uder M, Horch RE; Deutschsprachige Gemeinschaft für Mikrochirurgie der peripheren Nerven und Gefäße. Reconstruction of the vascular compromised lower extremity - report of the consensus workshop at the 35. Meeting of the DAM (deutschsprachige gemeinschaft für mikrochirurgie der peripheren nerven und gefäße) 2013 in Deidesheim. Handchir Mikrochir Plast Chir 2014;46:248-55.

8. Demirtas Y, Ayhan S, Sariguney Y, Findikcioglu F, Cukurluoglu O, Latifoglu O, Cenetoglu S. Distally based lateral and medial leg adipofascial flaps: need for caution with old, diabetic patients. Plast Reconstr Surg 2006;117:272-6.

9. Dragu A, Bach AD, Kneser U, Horch RE. Two easy and simple modifications when using a distally based sural flap to reduce the risk of venous congestion. Plast Reconstr Surg, 2008;122:683-4; author reply 684.

10. Georgescu AV, Matei IR, Capota IM. The use of propeller perforator flaps for diabetic limb salvage: a retrospective review of 25 cases. Diabet Foot Ankle 2012; doi: 10.3402/dfa.v3i0.18978.

11. Hallock GG. A paradigm shift in flap selection protocols for zones of the lower extremity using perforator flaps. J Reconstr Microsurg 2013;29:233-40.

12. Horch RE, Horbach T, Lang W. The nutrient omentum free flap: revascularization with vein bypasses and greater omentum flap in severe arterial ulcers. J Vasc Surg 2007;45:837-40.

13. Kremer T, Bauer M, Zahn P, Wallner C, Fuchs P, Horch RE, Schaefer DJ, Bader RD, Lehnhardt M, Reichert B, Pierer G, Hirche C, Kneser U. Perioperative management in microsurgery - consensus statement of the German Speaking Society for Microsurgery of Peripheral Nerves and Vessels. Handchir Mikrochir Plast Chir 2016;48:205-11.

14. Ludolph I, Lehnhardt M, Arkudas A, Kneser U, Pierer G, Harder Y, Horch RE. Plastic reconstructive microsurgery in the elderly patient Consensus statement of the German Speaking Working Group for Microsurgery of the Peripheral Nerves and Vessels. Handchir Mikrochir Plast Chir 2018;50:118-25.

15. Rother U, Krenz K, Lang W, Horch RE, Schmid A, Heinz M, Meyer A, Regus S. Immediate changes of angiosome perfusion during tibial angioplasty. J Vasc Surg 2017;65:422-30.

16. Donski PK, Fogdestam I. Distally based fasciocutaneous flap from the sural region. A preliminary report. Scand J Plast Reconstr Surg $1983 ; 17: 191-6$.

17. Masquelet AC, Romana MC, Wolf G. Skin island flaps supplied by the vascular axis of the sensitive superficial nerves: anatomic study and clinical experience in the leg. Plast Reconstr Surg 1992;89:1115-21.

18. Lyle WG, Colborn GL. The peroneus brevis muscle flap for lower leg defects. Ann Plast Surg 2000;44:158-62.

19. Kneser U, Bach AD, Polykandriotis E, Kopp J, Horch RE. Delayed reverse sural flap for staged reconstruction of the foot and lower leg. Plast Reconstr Surg 2005;116:1910-7.

20. Al-Qattan MM. The reverse sural artery fasciomusculocutaneous flap for small lower-limb defects: the use of the gastrocnemius muscle cuff as a plug for small bony defects following debridement of infected/necrotic bone. Ann Plast Surg 2007;59:307-10.

21. Follmar KE, Baccarani A, Baumeister SP, Levin LS, Erdmann D. The distally based sural flap. Plast Reconstr Surg 2007;119:e138-48.

22. Bullocks JM, Hickey RM, Basu CB, Hollier LH, Kim JY. Single-stage reconstruction of Achilles tendon injuries and distal lower extremity 
soft tissue defects with the reverse sural fasciocutaneous flap. J Plast Reconstr Aesthet Surg 2008;61:566-72.

23. Reyes S, Andrades P, Fix RJ, Vasconez LO. Distally based superficial sural fasciomusculocutaneous flap: a reliable solution for distal lower extremity reconstruction. J Reconstr Microsurg 2008;24:315-22.

24. Abhyankar SV, Kulkarni A, Agarwal NK. Single stage reconstruction of ruptured tendoachilles tendon with skin cover using distally based superficial sural artery flap. Ann Plast Surg 2009;63:425-7.

25. McHenry TP, Early JS, Schacherer TG. Peroneus brevis rotation flap: anatomic considerations and clinical experience. J Trauma 2001;50:922-6.

26. Eren S, Ghofrani A, Reifenrath M. The distally pedicled peroneus brevis muscle flap: a new flap for the lower leg. Plast Reconstr Surg 2001;107:1443-8.

27. Koski EA, Kuokkanen HO, Tukiainen EJ. Distally-based peroneus brevis muscle flap: a successful way of reconstructing lateral soft tissue defects of the ankle. Scand J Plast Reconstr Surg Hand Surg 2005;39:299-301.

28. Yang YL, Lin TM, Lee SS, Chang KP, Lai CS. The distally pedicled peroneus brevis muscle flap anatomic studies and clinical applications. J Foot Ankle Surg 2005;44:259-64.

29. Fansa H, Frerichs O, Schneider W. Distally pedicled peroneus brevis muscle flap for defect coverage on the lower leg. Unfallchirurg 2006;109:453-6.

30. Nahai F, Mathes SJ. Musculocutaneous flap or muscle flap and skin graft? Ann Plast Surg 1984;12:199-203.

31. Troisi L, Wright T, Khan U, Emam AT, Chapman TWL. The distally based peroneus brevis flap: the 5-step technique. Ann Plast Surg 2018;80:272-6.

32. Lorenzetti F, Lazzeri D, Bonini L, Giannotti G, Piolanti N, Lisanti M, Pantaloni M. Distally based peroneus brevis muscle flap in reconstructive surgery of the lower leg: postoperative ankle function and stability evaluation. J Plast Reconstr Aesthet Surg 2010;63:152333.

33. Rodriguez Collazo ER, Bibbo C, Mechell RJ, Arendt A. The reverse peroneus brevis muscle flap for ankle wound coverage. J Foot Ankle Surg 2013;52:543-6.

34. Antonini A, Rossello C, Salomone C, Riccio G, Felli L, Burastero G. The peroneus brevis flap in the treatment of bone infections of the lower limb. Injury 2017;48 Suppl 3:S76-9.

35. Kneser U, Beier JP, Dragu A, Arkudas A, Horch RE. Peroneal artery perforator flap. Oper Orthop Traumatol 2013;25:170-5.

36. Kneser U, Brockmann S, Leffler M, Haeberle L, Beier JP, Dragu A, Unglaub F, Bach A, Horch RE. Comparison between distally based peroneus brevis and sural flaps for reconstruction of foot, ankle and distal lower leg: an analysis of donor-site morbidity and clinical outcome. J Plast Reconstr Aesthet Surg 2011;64:656-62.

37. Horch RE, Weigand A, Wajant H, Groll J, Boccaccini AR, Arkudas A. Biofabrication: new approaches for tissue regeneration. Handchir Mikrochir Plast Chir 2018;50:93-100.

38. Arkudas A, Lipp A, Buehrer G, Arnold I, Dafinova D, Brandl A, Beier JP, Körner C, Lyer S, Alexiou C, Kneser U, Horch RE. Pedicled transplantation of axially vascularized bone constructs in a critical size femoral defect. Tissue Eng Part A 2018;24:479-92.

39. Yuan Q, Arkudas A, Horch RE, Hammon M, Bleiziffer O, Uder M, Seuss H. Vascularization of the arteriovenous loop in a rat isolation chamber model-quantification of hypoxia and evaluation of its effects. Tissue Eng Part A 2018;24:719-28.

40. Weigand A, Tasbihi K, Strissel PL, Strick R, Horch RE, Boos AM. Development of an innovative cell isolation method for the investigation of breast cancer pathogenesis and angiogenesis for experimental in vitro and in vivo assays. Handchir Mikrochir Plast Chir, 2017;49:11122.

41. Weigand A, Beier JP, Schmid R, Knorr T, Kilian D, Götzl R, Gerber T, Horch RE, Boos AM. Bone tissue engineering under xenogeneicfree conditions in a large animal model as a basis for early clinical applicability. Tissue Eng Part A 2017;23:208-22.

42. Vielreicher M, Gellner M, Rottensteiner U, Horch RE, Arkudas A, Friedrich O. Multiphoton microscopy analysis of extracellular collagen I network formation by mesenchymal stem cells. J Tissue Eng Regen Med 2017;11:2104-15.

43. Steiner D, Köhn K, Beier JP, Stürzl M, Horch RE, Arkudas A. Cocultivation of mesenchymal stem cells and endothelial progenitor cells reveals antiapoptotic and proangiogenic effects. Cells Tissues Organs 2017;204:218-27.

44. Schmidt VJ, Covi JM, Koepple C, Hilgert JG, Polykandriotis E, Bigdeli AK, Distel LV, Horch RE, Kneser U. Flow induced microvascular network formation of therapeutic relevant arteriovenous (AV) loop-based constructs in response to ionizing radiation. Med Sci Monit 2017;23:834-42.

45. Rottensteiner-Brandl U, Distel L, Stumpf M, Fey T, Köhn K, Bertram U, Lingens LF, Greil P, Horch RE, Arkudas A. Influence of different irradiation protocols on vascularization and bone formation parameters in rat femora. Tissue Eng Part C Methods 2017;23:583-91.

46. Dippold D, Cai A, Hardt M, Boccaccini AR, Horch R, Beier JP, Schubert DW. Novel approach towards aligned PCL-Collagen nanofibrous constructs from a benign solvent system. Mater Sci Eng C Mater Biol Appl 2017;72:278-83.

47. Chakraborty D, Šumová B, Mallano T, Chen CW, Distler A, Bergmann C, Ludolph I, Horch RE, Gelse K, Ramming A, Distler O, Schett G, Šenolt L, Distler JHW. Activation of STAT3 integrates common profibrotic pathways to promote fibroblast activation and tissue fibrosis. Nat Commun 2017;8:1130.

48. Weigand A, Beier JP, Arkudas A, Al-Abboodi M, Polykandriotis E, Horch RE, Boos AM. The arteriovenous (AV) loop in a small animal model to study angiogenesis and vascularized tissue engineering. J Vis Exp 2016; doi: 10.3791/54676. 
49. Seuss H, Arkudas A, Hammon M, Bleiziffer O, Uder M, Horch RE, Yuan Q. Three-dimensional mapping of the arteriovenous loop model using two-dimensional histological methods. Microsc Res Tech 2016;79:899-907.

50. Leibig N, Wietbrock JO, Bigdeli AK, Horch RE, Kremer T, Kneser U, Schmidt VJ. Flow-induced axial vascularization: the arteriovenous loop in angiogenesis and tissue engineering. Plast Reconstr Surg 2016;138:825-35.

51. Polykandriotis E, Arkudas A, Euler S, Beier JP, Horch RE, Kneser U. Prevascularisation strategies in tissue engineering. Handchir Mikrochir Plast Chir 2006;38:217-23.

52. Kneser U, Beier JP, Schmitz M, Arkudas A, Dragu A, Schmidt VJ, Kremer T, Horch RE. Zonal perfusion patterns in pedicled free-style perforator flaps. J Plast Reconstr Aesthet Surg 2014;67:e9-17.

53. Horch RE, Lang W, Arkudas A, Taeger C, Kneser U, Schmitz M, Beier JP. Nutrient free flaps with vascular bypasses for extremity salvage in patients with chronic limb ischemia. J Cardiovasc Surg (Torino) 2014;55:265-72.

54. Kneser U, Arkudas A, Beier JP, Dragu A, Stübinger A, Lang W, Horch RE. Extended skin and soft tissue defects after vascular wounds: plastic surgical concepts. Zentralbl Chir 2013;138:536-42.

55. Rother U, Lang W, Horch RE, Ludolph I, Meyer A, Gefeller O, Regus S. Pilot assessment of the angiosome concept by intra-operative fluorescence angiography after tibial bypass surgery. Eur J Vasc Endovasc Surg 2018;55:215-21.

56. Rother U, Lang W, Horch RE, Ludolph I, Meyer A, Regus S. Microcirculation evaluated by intraoperative fluorescence angiography after tibial bypass surgery. Ann Vasc Surg 2017;40:190-7.

57. Meyer A, Horch RE, Schoengart E, Beier JP, Taeger CD, Arkudas A, Lang W. Results of combined vascular reconstruction by means of AV loops and free flap transfer in patients with soft tissue defects. J Plast Reconstr Aesthet Surg 2016;69:545-53.

58. Meyer A, Goller K, Horch RE, Beier JP, Taeger CD, Arkudas A, Lang W. Results of combined vascular reconstruction and free flap transfer for limb salvage in patients with critical limb ischemia. J Vasc Surg 2015;61:1239-48.

59. Ensat F, Hladik M, Larcher L, Mattiassich G, Wechselberger G. The distally based peroneus brevis muscle flap-clinical series and review of the literature. Microsurgery 2014;34:203-8.

60. Panagiotopoulos K, Soucacos PN, Korres DS, Petrocheilou G, Kalogeropoulos A, Panagiotopoulos E, Zoubos AB. Anatomical study and colour Doppler assessment of the skin perforators of the anterior tibial artery and possible clinical applications. J Plast Reconstr Aesthet Surg 2009;62:1524-9.

61. Suh YC, Suh HP, Lee JS, Chang JS, Hong JPJ. Reconstruction using a perforator free flap after malignant melanoma resection of the ankle and foot. J Surg Oncol 2017;116:862-9.

62. Acartürk TO, Tunc S, Acar F. Versatility of the perforator-based adipose, adipofascial, and fasciocutaneous flaps in reconstruction of distal leg and foot defects. J Foot Ankle Surg 2016;55:362-7.

63. de Rezende MR, Saito M, Paulos RG, Ribak S, Abarca Herrera AK, Cho ÁB, Mattar R Jr. Reduction of morbidity with a reverse-flow sural flap: a two-stage technique. J Foot Ankle Surg 2018;57:821-5.

64. Deng C, Wu B, Wei Z, Li H, Zhang T, Wang D. Interperforator flow pattern and clinical application of distal extended peroneal artery perforator flaps. Ann Plast Surg 2018;80:546-52.

65. Ebrahiem AA, Manas RK, Vinagre G. Distally based sural artery peroneus flap (DBSPF) for foot and ankle reconstruction. Plast Reconstr Surg Glob Open 2017;5:e1276.

66. Masood T, Ahmed R, Obaidullah. Use of a special splint in reverse sural artery flap to reduce venous congestion and flap necrosis. J Ayub Med Coll Abbottabad 2016;28:63-6.

67. Cheng Z, Wu W, Hu P, Wang M. Distally based saphenous nerve-greater saphenous venofasciocutaneous flap for reconstruction of soft tissue defects in distal lower leg. Ann Plast Surg 2016;77:102-5.

68. Chen SL, Chen TM, Chou TD, Chen SG, Wang HJ. The distally based lesser saphenous venofasciocutaneous flap for ankle and heel reconstruction. Plast Reconstr Surg 2002;110:1664-72.

69. Lee HI, Ha SH, Yu SO, Park MJ, Chae SH, Lee GJ. Reverse sural artery island flap with skin extension along the pedicle. J Foot Ankle Surg 2016;55:470-5.

70. Grandjean A, Romana C, Fitoussi F. Distally based sural flap for ankle and foot coverage in children. Orthop Traumatol Surg Res 2016;102:111-6.

71. Schannen AP, Truchan L, Goshima K, Bentley R, DeSilva GL. Sural Versus Perforator Flaps for Distal Medial Leg Wounds. Orthopedics 2015;38:e1059-64.

72. Chang SM, Li XH, Gu YD. Distally based perforator sural flaps for foot and ankle reconstruction. World J Orthop 2015;6:322-30.

73. Mok WL, Por YC, Tan BK. Distally Based Sural Artery Adipofascial Flap based on a Single Sural Nerve Branch: Anatomy and Clinical Applications. Arch Plast Surg 2014;41:709-15.

74. Ludolph I, Arkudas A, Schmitz M, Boos AM, Taeger CD, Rother U, Horch RE, Beier JP. Cracking the perfusion code?: Laser-assisted indocyanine green angiography and combined laser Doppler spectrophotometry for intraoperative evaluation of tissue perfusion in autologous breast reconstruction with DIEP or ms-TRAM flaps. J Plast Reconstr Aesthet Surg 2016;69:1382-8. 